\title{
MICROSTRUCTURE AND MAGNETIC PROPERTIES
}

OF Fe-Cr-Co-V ALISOYS

\author{
Y. Belli, M. Okada, G. Thomas \\ Department of Materlals Science and Mneral Engineering \\ Materlals and Molecular Research Division \\ Lawrence Berkeley Laboratory \\ University of Californta \\ Berkeley, Californta 94720
}

M. Homma and $\mathrm{H}$. Kaceko

Department of Materials Science

Faculty of Engineerlag,

Tohoku UnIversity, Senda1, Japan 980.

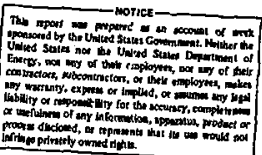

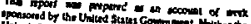

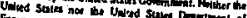

milorices, nites

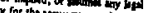

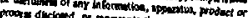

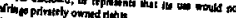


MICROSTRUCTURE ARD MAGNETIC PROPERTIES

OF Fe-Cr-Co-V ALLOYS

Y. Bell1, M. Okada, G. Thomas

Department of Materials Science and Mineral Engineering

Materials and Molecular Research plvision

Lawrence Berkeley Laboratory

University of California

Berkeley, California 94720

M. Homma and $\mathrm{H}$. Kaneko

Department of Materlals Science

Faculry of Engineering,

Tohoku University, Senda1, Japan 980.

\section{ABSTRACT}

The relationship betwee:s the microstructure and magnet1c properties of hect treated Fe-23wt\%Cr-15wt\%Co-5wt\%V has been studled by tranamission electron milcroscopy and Loreatz microscopy. Three different heattreatments were adopted 'for the present investigations v1z., 1) isothermal aging, 2) TiT (therwonsánetlc treatment) + step-aging, 3) continuous cooling: It has been found that the magnetic properties of the alloy are very sensitive to the temperature of the thermomagnetic treatment. StepagIng gave the best magnetic properties, producing an elongated ferromagnetic phase, $300 \AA$ In diameter and $1200 \AA$ In length. Loreatz microscopy

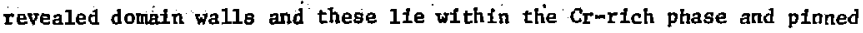
by the Fe-rich phase in the Isothermally aged alloy at $650^{\circ} \mathrm{C}$. Magnetic domains of optfrally step-aged a1loy, $0.5 \mu \mathrm{m}$ in width; are elongated along 
the direction of the applied magnetic fleId. The results suggest that the magnetlc anisotropy is introduced parallel to the direction of the . applied magnetic fịeld during WMI and step-aging treatments.

\section{INTRODOCTION}

$\mathrm{Fe}-\mathrm{Cr}-\mathrm{Co}-\mathrm{V}$ alloys are potentlal duct $11 \mathrm{e}$ permanent magnets with properties comparable to those of Alnico 5, which cen be easily heat treated to produce optimum properties. (1) Previous work has concentrated on the hase ternary Fe.Cr-Co alloy in which the microstructures and phase relationships are well characterized $(2,3)$ The present investigatton describes the microstructural changes of an Fe-23wtyCr-15wt\%Co-5wt\%V alloy with various heat treatments (isothermal aging, thermomegnetlc treatment, step-aging and continuous cooling). using electron wicroscopy. Since magnetic hardening of the alloy occurs on a very fine scale, ${ }^{(3)}$ transmission Lorent $z$ electron microscopy has been used to study the magnetic domain structures, in an attempt to underatand the magnetization reversal process of the alloy.

\section{EXPPERIMENTAL PROCEDURES}

An Fe-23wt\%Cr-15wt\%Co-5wt\% alloy was homogentzed at $1000^{\circ} \mathrm{C}$ for 1 hour In an argon atposphere and, quenched in ice vater. The specimens were given varfous heat-treatments, and the magnetic properties of the specimen were measured with an automatic flux meter. Spectmens for electron microscopy were thinned in an automatle jet polisher using an electrolytic solution of 23\% perchiorle acld and $77 \%$ acetic acid. Magnotic domaln walls and domain configuration of the specimens were observed by the out-of-focus and displaced aperture methods $(4,5)$ 


\section{RESULTS AND DISCUSSTON}

\section{A. MAcrostructure}

(1) Isothermai aging. The brtght field micrograpis (B.F.) shown tr Fig. 1 are taken from the alloy aged for 1 hour at $660^{\circ} \mathrm{S}, 650^{\circ} \mathrm{C}, 640^{\circ} \mathrm{C}$ and $630^{\circ} \mathrm{C}$, respectively. The phase w1th bright contrast is the Fe-rich phase $\left(\alpha_{1}\right)$ and the one with dark contrast jis the Cr-rich phase $\left(\mathrm{a}_{2}\right)(3)$ These micrographs suggest that the morphology of the microstructure and the volume fractions of the two phases are very sensitive to the aging temperature, 1.e., the lower the aging temperacures, the finer the $\alpha_{1}$ phase. The $\dot{\alpha}_{1}$ phase appears as rod shaped partlcles which become interconnected after aging at $640^{\circ} \mathrm{C}$. These results are important in understanding the effect of thermorrenetic treatment (TMT) of the alloy at these temperatures.

(2) Thernomagnetic treatment and step-aging. It is reported that thermomagnetic treatment and step-aging have a beneficial effect on improving the nagnetic properties of the system. $(1,3,6)$ Four different temperatures of thermomagnetic treatment (TMT) were chosen to investigate the effect of the TMT temperature on the magnetic properties and their microstructures. After TMT in a magnetic field of $2 \mathrm{kOe}$, the alloy was stepaged at $620^{\circ} \mathrm{C}, 600^{\circ} \mathrm{C}, 580^{\circ} \mathrm{C}, 560^{\circ} \mathrm{C}$ for 1 hour and subsequently aged at $540^{\circ} \mathrm{C}$ for 5 hours.

Fig, 2 Illustrates the B.F. micrographs of the step-aged alloy after different $\operatorname{TMT}$ at (a) $660^{\circ} \mathrm{C}\left(\mathrm{H}_{\mathrm{c}} 420 \mathrm{Ge}\right),(\mathrm{b}) 650^{\circ} \mathrm{C}\left(\mathrm{H}_{\mathrm{c}}-520 \mathrm{Oe}\right)$,

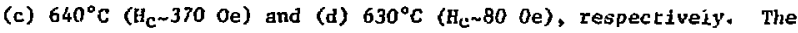
coercive force of the alloy is remarkably affected by the temperature of the TMT. For exanple, Fig. 2(a) shows two morphologies of the $\alpha y$ phase viz., elongated $\alpha_{1}$ particles, $300 \AA$ in díameter, and spherical $\alpha_{1}$ particles, $135 \AA$ in diameter. Since the larger $\alpha_{1}$ particles are elongated, thev should 
be formed during Th, ytilat the onall $\alpha_{1}$ wist be nucleaced of ter TMT. These morphologies are produced when the step-aging thesval $(\Delta T)$ between

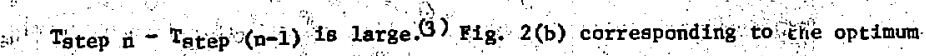
() properties shows the $\alpha_{1}$ phage, approxinately $300 \AA$ In diameter and $1200 \AA$ in length, giving an aspect ratio of 4 . In Fig. 2 (c) and 2 (d), the rod diameter 1a about $200 \AA$ and $140 \AA$, and the length about $400 \AA$ and $220 \AA$ respectively The fine ophericsl particles are absent In Fig. 2 (c) and (d). This Is belleved to be due to the fact that the step-aging Interval is sma11.

It is cancluded that the morphology of mitcrostructure and the shape or size of the ferromagnetic phase is very gensitive to the TMT temperature, resulting. In different magretic pzoperties. This emphasizes that careful temperature control is needed to produce good magnetic properties.

(3) Continuous cooling. The otep-aging process can be facilitated by continuous cooling, giving optimum magnetic properties. ${ }^{(1)}$ In order to atudy the effect of continuous cooling rate on the magnetic properties and their microstructures, the alloy was thermomagnetically treated at $650^{\circ} \mathrm{C}$ for $1 \mathrm{hr}$ since $650^{\circ} \mathrm{C}$ is the besc tempesature for $\mathrm{TMT}$, and then continuously cooled to $540^{\circ} \mathrm{C}$.

Fig. 3 shows the micrographs of the alloys continuously-cooled at the rate of (a) $1^{\circ} \mathrm{C} / \mathrm{min}$ (Hc $220 \mathrm{Oe}$ ) and of (b) $0.25^{\circ} \mathrm{C} / \mathrm{min}$ (He $520 \mathrm{Oe}$ ). These micrographs suggest that the morphology of the microstructure appears to be very sinflar, almost independently of the cooling rate. Since both specimens have the sime IHT, the morphology of the microstructure must be egtablished during TMT. ThLs observation is similar to those observed in Alnico alloys.(7)

The coerclve force of the fast cooled $\left(1^{\circ} \mathrm{C} /\right.$ nitin $)$ specimens can be remarkably increased fron 220 oe to 520 oe by isothermal aging at $540^{\circ} \mathrm{C}$ 
for 14.5 hours after continuous cooling. But the coerclive force of optimally cooled spectmen (0.25 $\mathrm{C} / \mathrm{min}$ ) increases from 520 oe to oniy 590 Oe by the same treatment. It has been cbserved that there is no noticeable difference In morphology of the microstructures between continuously cooled and low temperature aged alloys after continuous cooling. These results Imply that the composition of the two phases differs dependIng on the continuous cooling rate, glving different coerclve forces.

Therefore, there are two alternative methods to produce the optimum properties in this alloy. One is by continuous cooling at a rate. of $0.25^{\circ} \mathrm{C} /$ min. The other is by cooling at a rate of $1^{\circ} \mathrm{C} / \mathrm{min}$ and subsequently. aging at low temperatures for long times.

\section{B. Domain Structures}

F1g. 4 shows the domain wall of the isothermally aged alloy at $650^{\circ} \mathrm{C}$. for $1 \mathrm{hr}$, Imaged by the defocus method. The domaln walls appear to be straight. From this micrograph it is uncertain where the domain wall exactly lies. To solve these uncertainties, the alloy was further agef at $650^{\circ} \mathrm{C}$ for $50 \mathrm{hrs}$, growling the $\alpha_{1}$ particle from $150 \AA$ (In FIg. 4) to $900 \AA$ in diameter.

F1g. 5 shows the Fresnel micrographs of the over-aged alloy, The domain wall wich black contrast (divergent wa11) Iles within the $\alpha_{2}$ matrix phase. This stems from the fact that the domaln wall energy of the $\alpha_{2}$ phase is 1ower than that of the $\alpha_{1}$ phase. After photographing FIg. 5(a), the specimen was taken out from the microscope and was fut In a magnetic fleld. Then it was obaerved that the domain wall changed its position before ( $\left.F I_{g} .5(a)\right)$, and after (Fig. 5(b)), applying the magnetic Fleld. In FIg. 5(b), the dotualn wall exists in the $\alpha_{2}$ phase and 1 sitghtly bent around the $\alpha_{1}$ particles. These figures substantiate 
that domaln walis are plnned by the $\alpha_{1}$ phase. It is concluded that the magnetization process oft the fsothermally aged alloy is due to domatn wall pinntug. Thus the coerifive force would be given by the difference in wall energy of the two phases; $H c^{\alpha}\left(W \alpha_{1}-W \alpha_{2}\right)$, where $W \alpha_{1}$ is the wall energy of the $\alpha_{1}$ phase and $\alpha_{2}$ that of the $\alpha_{2}$ phase. Thts mechantsm has also been proposed for $\mathrm{Sm}\left(\mathrm{Co}_{3} \mathrm{Cu}, \mathrm{Fe}\right) 7$ magnets $(8)$

F1g. $6(\mathrm{a})$ and $6(\mathrm{~b})$ are.the Fresnel mierographs of the optimally step-àged alloy, showlng a domatn wal1, and $F I_{g} .6(c)$ and $6(d)$ are the Foucault miczographs (displaced aperture method). The observed domain wall is not straight. The domains are approximately $0.5 \mu$ wide, elongated along the direction of the applied magnetic field, and their size is smaller than that of the isothermally-aged alloy. The Foucault micrograph with higher magnification, as shown in PIg. 7 111ustrates these features more clearly. The dowain with black contrast is almost $1500 \AA$ wide and is elongated in the direction of the applied magnetic field (the direction in which the $\alpha_{1}$ phase ts elongated). These observations suggest that the aganetic anisotropy is introduced parallel to the direction of the applied magnet:lc field after TMT and step-aging. Since the contrast mechanlism of the magnetically Inhomogeneous material $\left(\alpha_{1}\right.$ and $\alpha_{2}$ phase) In Lorentz microscopy is complex, more experiments are needed to interpret the nature of the imaged domain walls in detail.

\section{ACKIYOWLEDGEMENTS}

Th1s research is sponsored by the United States Research Development Adminfstration through the Isawrence Berkeley Laboratory 


\section{REFERENCES}

1. H. Kaneko, M. Holma and T. Minowa, "Effects of V and V + TI Additions on the Structure and Properties of Fe-Cr-Co Ductile Magnets", IEEE Trans. Magnetics, Mag-12, 177 (1976).

2. H. Kaneko, M. Honma, K. Nakamura, M. Okada, G. Thomas, "Phase DĖagram of Fe-Cr-Co Permanent Magnet System", IEEE Trans. Magnetics, Mag-13, 1325 (1.977).

3. M. Okada, G. Thomas, H. Kaneko, K. Homma, "Magnet1c Properties and Microstructures of Fe-Cr-Co Alloys". to be published.

4. P.B. Hirsch, et a1., "Electron Microscopy of ThIn Crystals", Chap. 16, Butterworths, London, 1965.

5. J. P. Jakubovics, "Lorentz Microscopy and Application (TEM and SEM)", Electron Microscopy in Materials Science, Part IV, Commission of the European Communities, 1975.

6. H. Kaneko, M. Honma; K. Nakamura, "New Ductile Permanent Magnet of Fe-Cr-Co System", AIP Conf. Proc., No. 5, 1088 (197I),

7. K. J. De Vos, "Alnico Permanent Magnet Matertals", Vol. 1, Magnetism and Metallurgy, 473 (Academic Press, 1969).

B. J. D. Livingston and D. L. Martin, "Microstructure of Aged (Co, $\mathrm{Cu}, \mathrm{Fe})_{7} \mathrm{Sm}$ Magnets", J. of Appl. Phys., 48, 1350 (1.977). 


\section{FIGURE CAPTIONS}

F1g. 1. Bright, Fleld (B.F.) mferography taken from the Isothermally aged alloy: for 1 hr at (a). $660^{\circ} \mathrm{C}$, (b) $650^{\circ} \mathrm{C}$, (c) $640^{\circ} \mathrm{C}$ and (d) $630^{\circ} \mathrm{C}$.

F1g. 2. B.F. micrographs taken from the step-aged alloy after thermomagnetic treatment for 1 hr at (a) $660^{\circ} \mathrm{C}\left(\mathrm{H}_{\mathrm{c}} \sim 420 \mathrm{Oe}\right)$, (b) $650^{\circ} \mathrm{C}\left(\mathrm{H}_{\mathrm{c}} 520 \mathrm{Oe}\right)$, (c) $640^{\circ} \mathrm{C}\left(\mathrm{H}_{\mathrm{C}}-370 \mathrm{Oe}\right)$ and (d) $630^{\circ} \mathrm{C}$ $\left(\mathrm{H}_{\mathrm{C}} \div 80 \mathrm{Oe}\right)$.

Fig. 3. B.F. mfcrographs taken from the continuous cooled alloys after TMT at $650^{\circ} \mathrm{C}$ for 1 hr at a rate of (a) $1^{\circ} \mathrm{C} / \mathrm{min}\left(\mathrm{H}_{\mathrm{c}}-220 \mathrm{Oe}\right)$ and (b) $0.25^{\circ} \mathrm{C} / \mathrm{min}\left(\mathrm{H}_{\mathrm{c}} \sim 520 \mathrm{Oe}\right)$.

F1g. 4. Fresnel micrographs taken from the alloy aged at $650^{\circ} \mathrm{C}$ for $1 \mathrm{hr}$.

F18. 5. Fresnel micrographs taken from the alloy aged at $650^{\circ} \mathrm{C}$ for 50 hrs, showing the domain wall is pinned by the $\alpha_{1}$ particle.

F1g. 6. Fresne1 [(a), (b)] and Foucault mfcrographs [(c), (d)] of the step-aged alloy after TMT at $650^{\circ} \mathrm{C}$ for 1 hr $\left(\mathrm{H}_{\mathrm{c}} \sim 520 \mathrm{Oe}\right)$.

F1g. 7. Foucault micrographs of the step-aged alloy after TMT at $650^{\circ} \mathrm{C}$ for $1 \mathrm{hr}$. 

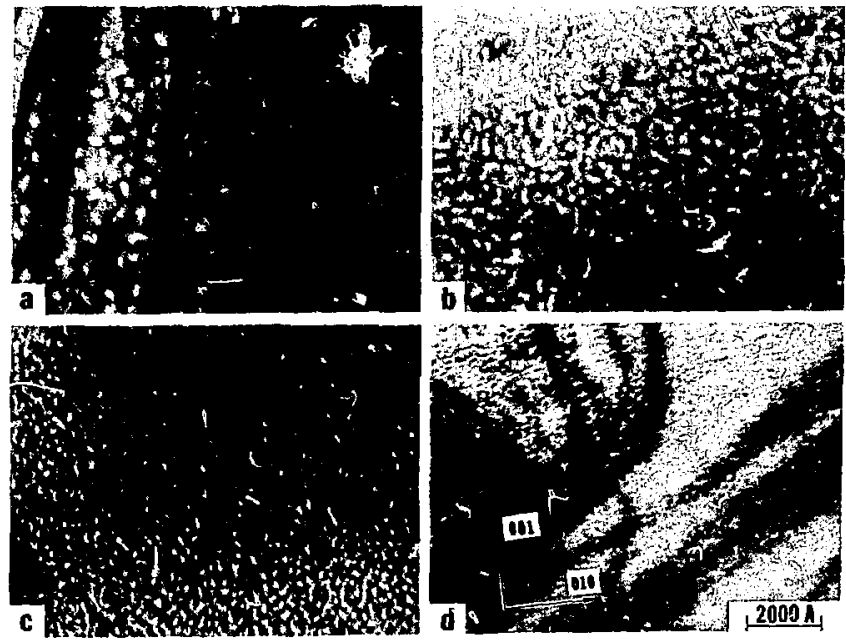

XBB 770-10356

Fig:' 1 

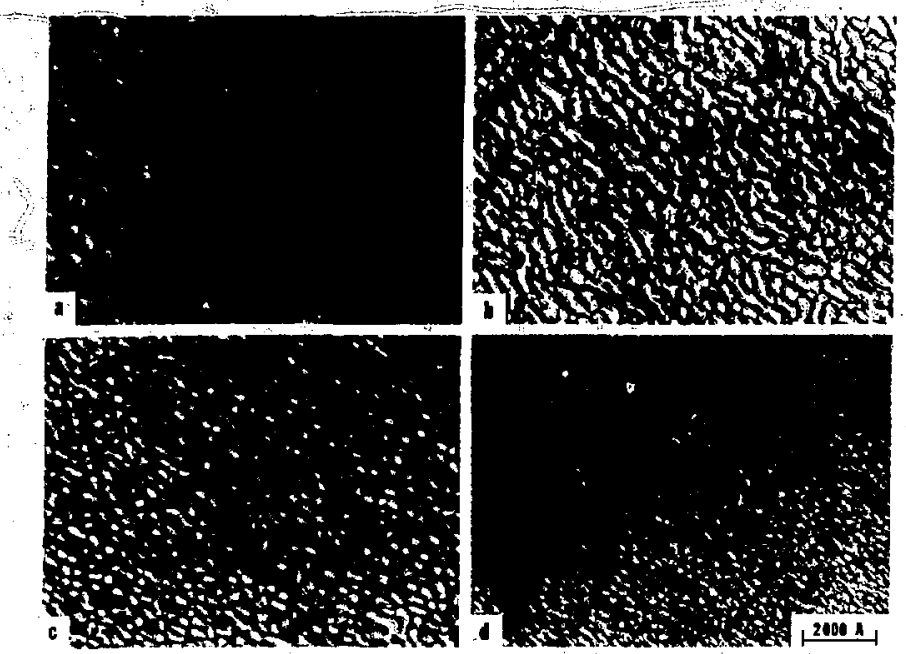

XBB 779-9128

FIg, 2 


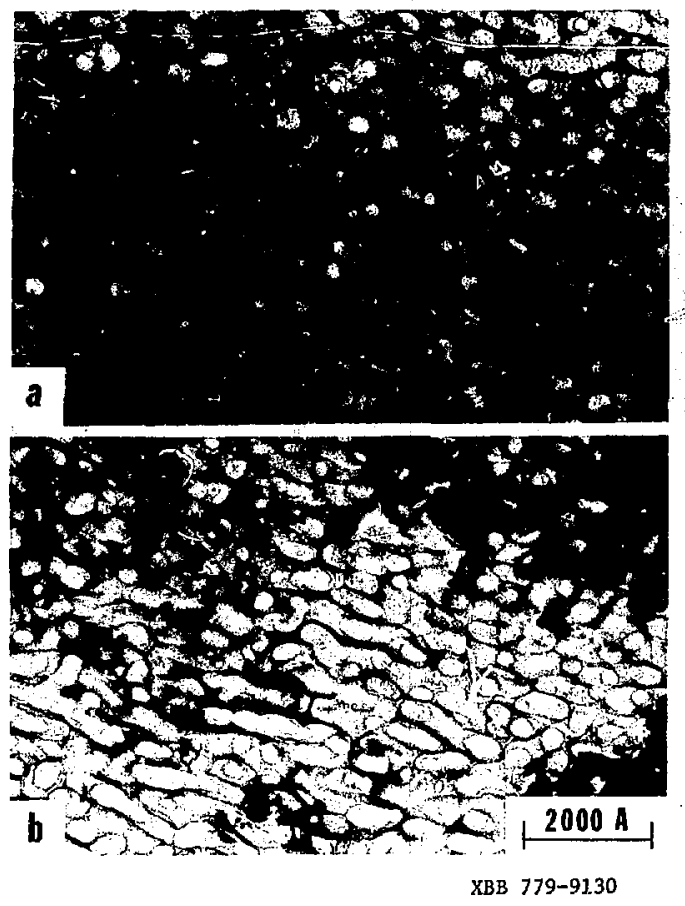

F十马. 3 

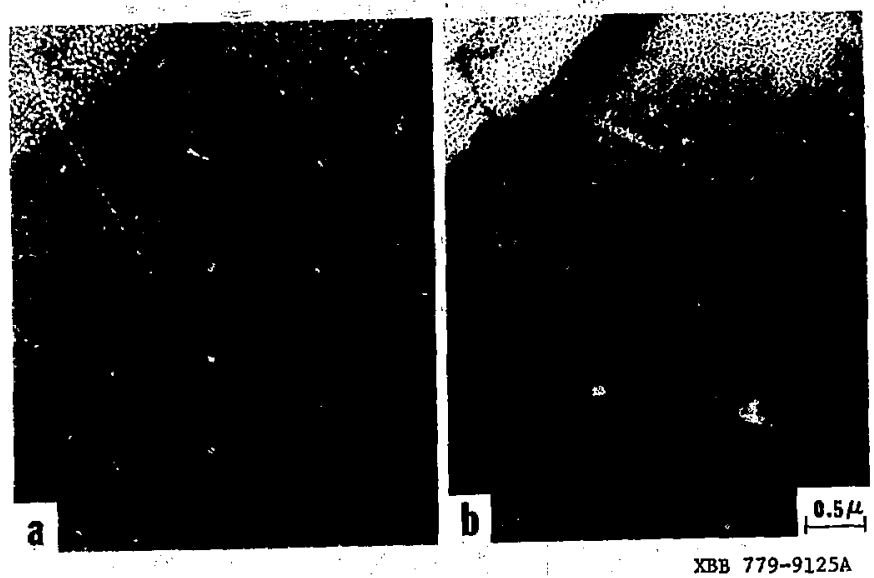

FIg. 4 


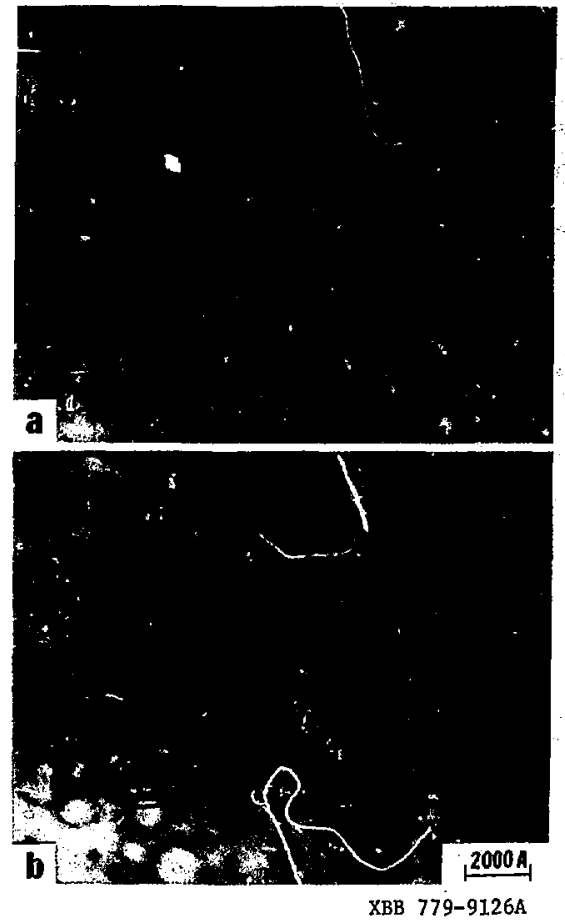

FIg. 5 


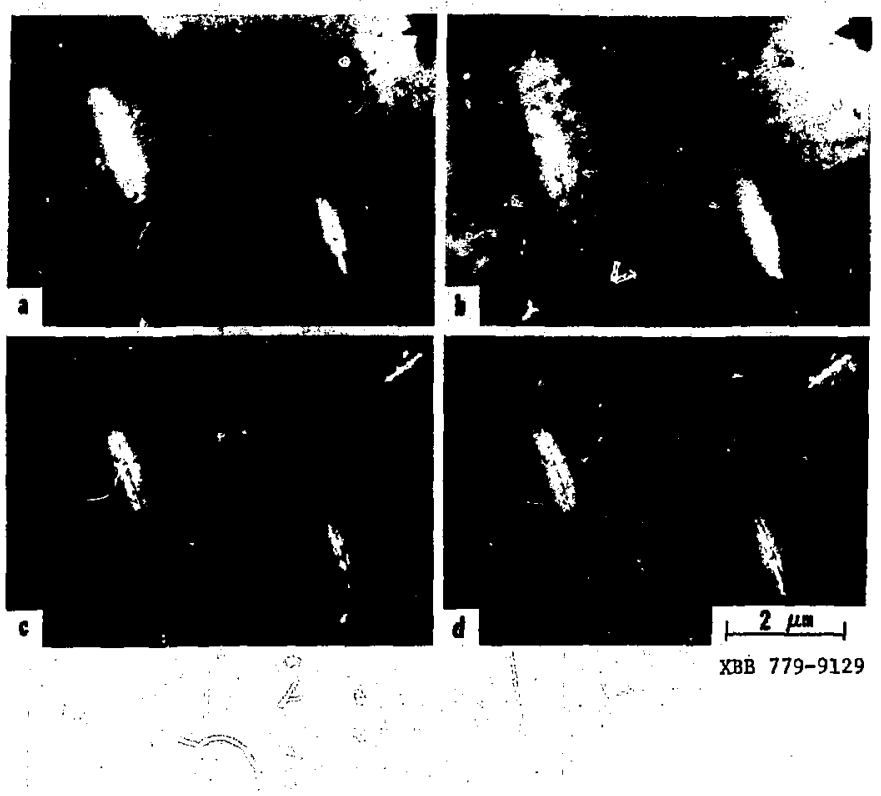

FIB - 6 


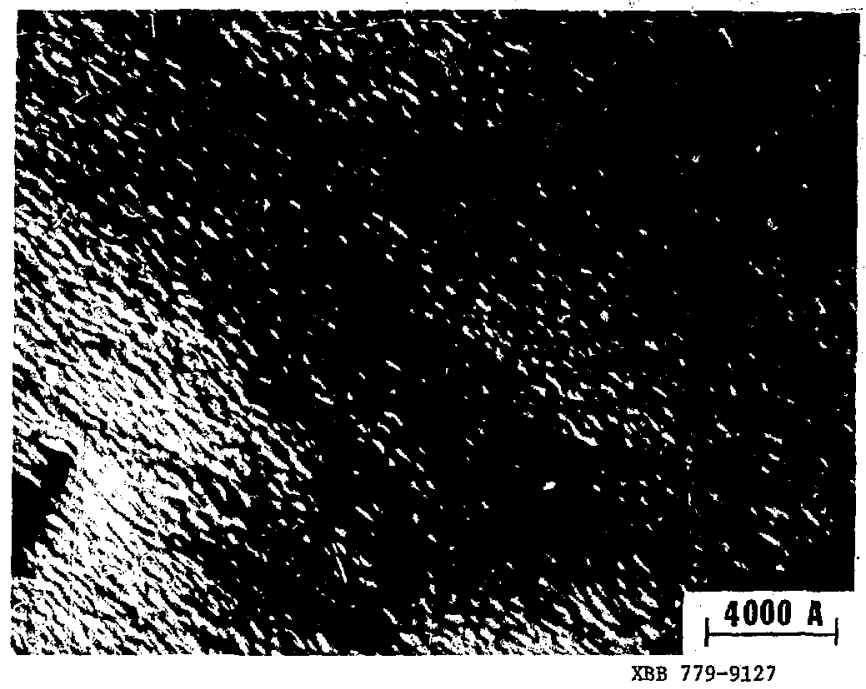

Fig, 7 